\title{
Modernization of agrarian and cooperative education systems as a basis of sustainable development of regional rural economics
}

\author{
Larisa V. Obedkova \\ Volgograd State University, \\ Institute of management and regional economy, \\ Volgograd, Russia \\ laravik@bk.ru
}

\author{
Tatiana V. Opeikina \\ Volgograd Institute of Cooperation (branch of) \\ Russian Cooperative University \\ Faculty of management and law, \\ Volgograd, Russia \\ otv06@bk.ru
}

\author{
Natalia I. Korobkina \\ Volgograd State Socio-pedagogical University, \\ Institute of foreign languages, \\ Volgograd, Russia \\ nataliakor88@yahoo.com
}

\begin{abstract}
In the article the relevance of personnel training for modern economy in general and for agrarian and cooperative sectors in particular is proved. The importance of a system approach use to educational processes organization is emphasized. Statistical data are analysed, in which the results of personnel training of Russian agricultural enterprises are reflected, including a regional level. The authors consider an agrarian and cooperative formation system of the Volgograd region and emphasize that the increase of experts' educational level is substantially connected with some modernization processes happening in these systems.
\end{abstract}

Keywords - personnel, personnel training, regional economy, economy agrarian sector, economy cooperative sector, system approach, consumer cooperation, professional competences

\section{INTRODUCTION}

In a modern competitive environment requirements to personnel qualification, skills and experience increase permanently. Competent and motivated workers are that driving force which allows to achieve strategic and tactical targets of any organization.

In the recent years the main problem in the field of personnel training are contradictions between the need of society in professionally trained employees and established practices of their preparation. Unfortunately, the obsolescence of knowledge gained in the course of secondary professional or higher education happens to accelerate. Therefore, the need for continuous updating and obtaining additional knowledge has ripened. In other words, it is about new methods and technologies of personnel training, which would allow to compensate some gaps of traditional training methods. For example, in the USA there is even a peculiar index of employees' knowledge obsolescence - it is a so-called "halflife period of competence" that means a period after the end of training, during which some gained knowledge becomes outdated for $50 \%$ [1]. By experts' estimates in such branches as economy, management, technique and high technologies knowledge updating equals to three years, respectively competences' half-life period is equated approximately by one and a half years.

Now both in our country and abroad issues of personnel training are resolved in different ways and first of all they are connected with the development of highly specialized and corporate forms. However, the interpretation of personnel training remains traditional. Training is considered as a continuous process of obtaining new knowledge by employees and assimilation of new application-oriented skills of working by them. In our country the need of professional education development is felt more sharply and is caused in many respects by the need of the accelerated transition to an innovative type of business activity guiding [2].

The relevance of personnel training problems is inherent also for an agrarian sector of our country. As it is well-known, domestic agriculture serves as the base for the development of other sectors of economy, including cooperative sector development. It means that its progress cannot be provided without the enhancement of human resources forward. The research of upgrade opportunities of agrarian and cooperative education systems with the use of a system approach makes the purpose of our research. 


\section{MATERIALS AND METHODS (MODEL)}

The methodological basis of the conducted research, whose results are stated in this article, is a system approach, which is based on a general dialectic method of scientific knowledge. It is conventional that a dialectic representation is based on the fact that studied phenomena and processes are based on change and development, establishment of correlation connections, interaction and dynamics. At the same time this development reflects objective laws of material world existence and is understood through the unity and conflict of opposites. "Interrelation recognition of all parties of each object at each moment and orderliness determination of these connections allows us to address a system approach" [3].

When using a system approach, including education systems studying, any objects of a research are considered as the elements of some complete set connected with each other by certain relations, which form an internal system structure. This method allows to investigate any problem considering it as a peculiar system in interrelation with other problems, to consider both external and internal connections and aspects of its analysis. One of the main application conditions of a modern system approach to training is training consideration as a certain system of cumulative activity of a teacher and a pupil (a subject and an object) as a process and a result of acceptance and a system of knowledge assimilation. Training and education are always directed to the satisfaction of a state, a society and individual interests and needs. It provides a person with self-identification and self-realization in dynamically changing sociocultural and economic conditions. Therefore, a system approach allows him to provide the understanding of an interconnected components set forming a certain unity and interacting with each other [4].

In relation to our investigated problem - a problem of personnel training for cooperation and agriculture - the main idea of a system approach consists of the following: at the same time both to keep and to improve an agrarian formation system of the country and its regions due to synergetic effect. Advantages of a system approach to an educational space are obvious. For educational institutions it is first of all about efficiency increase, quality and prestige of agrarian and cooperative education. For students - it is possibilities of receiving continuous education, including at the expense of higher steps (for example, a magistracy), clear ideas of an employment possibility and prospects of a career movement on the received profession. Benefits are not also less obvious to agrarian and industrial complex enterprises: firstly, an opportunity to receive educational services proceeding from requirements of an agrarian enterprise, secondly, to have an opportunity to be engaged in personnel planning in long-term and short-term prospects, thirdly, to be engaged directly in professional development and experts' retraining, fourthly, the creation of conditions for research activization and an innovative activity in agriculture. It is known that in a modern economic space production includes all set of knowledge transformation into an innovative product according to the following scheme: "science - technology - product - market". Scientific knowledge develops technology, technology transformation promotes the emergence of innovative products, which already create new segments of a market. The permanence of these components will transform economy, including its agrarian and cooperative sectors.

\section{RESULTS AND DISCUSSION}

A. Nowadays personnel potential improvement in agricultural and cooperative organizations serves one of the basic factors of agro-industrial complex modernization in the Russian Federation in general. At the same time one has to note that both in agricultural and cooperative structures a professional personnel share has considerably decreased for the last decade despite the constant growth of university graduates of agricultural orientation. Unfortunately, there are often situations when personnel partners don't hurry to employ profile higher education institutions graduates as firstly they are interested in skilled experts and secondly are guided by their own needs in relation to personnel planning proceeding from a market situation. Unfortunately, in many respects modern agrarian scientific educational institutions are torn off from real requirements of agrarian and industrial complex branches. However, the demand of their services is obvious (tab. 1) [5].

Table 1. Trained agriculture workers number on the Russian Federation territorial subjects (by data for 2016)

\begin{tabular}{|c|c|c|c|c|}
\hline & \multirow{2}{*}{$\begin{array}{l}\text { training in } \\
\text { reporting } \\
\text { year - all } \\
\text { people }\end{array}$} & \multicolumn{3}{|c|}{$\begin{array}{l}\text { including the following } \\
\text { programs }\end{array}$} \\
\hline & & $\begin{array}{l}\text { professio } \\
\text { nal } \\
\text { training } \\
\text { accordin } \\
\mathrm{g} \text { to } \\
\text { professio } \\
\text { ns }\end{array}$ & $\begin{array}{l}\text { retraini } \\
\text { ng }\end{array}$ & $\begin{array}{l}\text { professi } \\
\text { onal } \\
\text { develop } \\
\text { ment }\end{array}$ \\
\hline $\begin{array}{l}\text { Russian } \\
\text { Federation }\end{array}$ & 180839 & 32042 & 43033 & 105764 \\
\hline $\begin{array}{l}\text { Central } \\
\text { federal } \\
\text { district }\end{array}$ & 39656 & 6844 & 7702 & 25110 \\
\hline $\begin{array}{l}\text { Northweste } \\
\text { rn federal } \\
\text { district }\end{array}$ & 20102 & 2735 & 4662 & 12605 \\
\hline $\begin{array}{l}\text { Southern } \\
\text { federal } \\
\text { district }\end{array}$ & 19691 & 5324 & 5344 & 9023 \\
\hline $\begin{array}{l}\text { North } \\
\text { Caucasian } \\
\text { federal } \\
\text { district }\end{array}$ & 6572 & 978 & 2488 & 3106 \\
\hline $\begin{array}{l}\text { Ural federal } \\
\text { district }\end{array}$ & 22693 & 3717 & 4740 & 14236 \\
\hline
\end{tabular}

In this regard the Volgograd region is not an exception. It continues to remain a traditional agro-industrial region in the Russian Federation, where the questions of professional staff training for agricultural production are very relevant (tab. 2) [6].

So, statistical data demonstrate that the number of people who received additional professional education in educational 
institutions of Volgograd in 2014-2015 increases in comparison with 2012-2013. However for the beginning of 2016-17 academic year the number of students according to programs of secondary professional education has increased in comparison with the previous academic year by 10,3 thousand person (for 25,8\%) and in comparison with 2012-13 academic year has increased by 10,5 thousand people (for 26,7\%) and has been 50,0 thousand people [7].

At the same time mainly the educational level of workers creates that personnel potential necessary for agricultural and cooperative production development. Sustainable development prospect of modern agro-industrial complex of our country in many respects "... will be solved by people, their qualification, ability, labor motivation and culture. Therefore, training and retraining, professional development, staff formation gain a crucial importance for all the spheres of a complex" [8]. The world practice has also proved that mainly investments in human capital bring the greatest effect as knowledge and the level of workers competence are a basis for any enterprise development as well as the country in general [9].

Table 2. Workers number on personnel categories and age who have received additional professional education (in the organization direction or carried out by the organization itself) in the Volgograd region in 2016.

\begin{tabular}{|c|c|c|c|c|}
\hline \multirow{2}{*}{$\begin{array}{l}\text { All workers who } \\
\text { have received } \\
\text { additional } \\
\text { professional } \\
\text { education }\end{array}$} & \multicolumn{4}{|c|}{ on personnel categories } \\
\hline & chiefs & experts & $\begin{array}{l}\text { other } \\
\text { employe } \\
\text { es }\end{array}$ & $\begin{array}{l}\text { work } \\
\text { ers }\end{array}$ \\
\hline $\begin{array}{ll}\text { Workers } & \text { number } \\
\text { of a } & \text { payroll, } \\
\text { people } & \end{array}$ & 441756 & 35587 & 154767 & $\begin{array}{l}3829 \\
2\end{array}$ \\
\hline $\begin{array}{l}\text { Workers number } \\
\text { who have been } \\
\text { trained and have } \\
\text { received } \\
\text { education, people }\end{array}$ & 88196 & 11945 & 38334 & 3127 \\
\hline $\begin{array}{l}\text { Workers number } \\
\text { who have been } \\
\text { trained, have } \\
\text { received } \\
\text { education from } \\
\text { the workers total } \\
\text { number of a } \\
\text { payroll } \\
\text { personnel of } \\
\text { corresponding } \\
\text { categories and } \\
\text { age, in \% }\end{array}$ & 20 & 33,6 & 24,8 & 8,2 \\
\hline
\end{tabular}

B. One of the important ways of modern agrarian sector development in the Russian Federation (in particular its small farms) is cooperation. It is represented to us that cooperative connections development is a strategically important factor of rural territories modernization and the revival of domestic rural business. Despite the difficulties of its development and practicians and theorists ambiguous attitude towards it a cooperative sector in our country, as well as in many foreign countries, shows its ability to revival in developed economic conditions.

Today cooperation is not only a form of production organization and service on the basis of voluntary association of its participants, but also such a structure which allows to achieve quite impressive results in a national food market. According to the authors cooperation and its integration with small forms of agrobusiness have to be based on already habitual and historically repaid structures. As such it is necessary to call the system of consumer cooperation. Current Russian consumer cooperation activity has a separate character at the same time when maintaining its basic principle of functioning - the principle of systemacity, and it will never reach and revive in the scales of the former Soviet period in the development of our state any more. However, mainly consumer cooperatives work with small farms in a village than someone else. They create necessary conditions for the development of both small and medium business (for example, development of farms) and for personal subsidiary farms of villagers. For instance, in 2017 within state support measures for agricultural consumer cooperatives development the size of the grant means for farmers involved in meat and dairy cattle breeding was increased twice from 1,5 million to 3 million rubles, and for family livestock farms - to 30 million rubles (before 21,6 million), for creation of agricultural consumer cooperatives -846 million rubles [10]. Therefore, it is possible to claim confidently that a possibility of consumer cooperation revival both as an independent subject of market managing and as an instrument of integration with small forms of agrarian business is defined by such objective reasons as the use of internal system opportunities, development of stable sales channels and production processing, availability of financial services.

We believe that consumer cooperation (as well as other cooperative communities) has succeeded in keeping and developing competitive positions in many respects due to the existence of its profile education. Today's cooperative education system includes autonomous nonprofit organization of higher education of Central union of Russian Federation consumer societies "Russian Cooperative University" with the center in Moscow and 17 branches in regions of the Russian Federation. In cooperative higher education institutions the multilevel system of continuous training is implemented: preuniversity preparation, secondary professional education, higher professional education, postgraduate study, programs of professional development and additional professional education. Training is based on various forms of education. In our region the branch of Russian Cooperative University has existed since 1996 and has carried out training of specialists for agriculture and cooperative organizations of the Volgograd region and other regions for more than 20 years. It enters the seven of the largest higher education institutions of the Volgograd region.

Besides a number of socially oriented projects is implemented at the institute which are of great importance for the development of the regional consumer market and rural territories of the area in general. It is first of all about such programs as studying of population solvency, discount policy 
in rural areas, events for the revival of cooperative forms' organization of economical and economic activity in remote settlements.

Today Russian Cooperative University has proclaimed the purpose - to become a world-class higher education institution, a leader of enterprise education, professional and pedagogical training for small farms, cooperation, business [11].

On the basis of big data arrays analysis the university opens opportunities for the development of students and teachers, forms the realization platform of these opportunities which is based on their initiative. Connecting science and education with requirements of cooperation and business the university creates the generation system of expert contents and new technologies in the sphere of the university activity.

The university business model is based on value creation for three groups of stakeholders: students, scientific and pedagogical workers, personnel partners (companies and organizations) forming a system request for products of the university. At the university students plunge into the environment of potential disclosure, its converting into a social and professional capital, integration into modern economy on the basis of cooperation values, solidarity, sustainable development and responsibility for the life.

The university unites teachers, scientists, workers, giving them opportunities for professional creativity, scientific, pedagogical and enterprise search, disclosure and realization of potential. Personnel partners of the university get access to the latest technologies, a personnel pool, investigate new spheres of activity in cooperation together with the university creating joint scientific and educational programs.

The base for the university stable development are competitive advanced educational programs and a control system providing efficiency of educational activity.

The purpose of the university educational activity consists in conditions creation guaranteeing receiving the following products by the graduate of the university:

- personal core competences, including values, ethical installations, self-development competences, communication and other soft skills. It corresponds to a role "personality, member of society" - a person realizing his values, purposes and potential and who is effectively interacting with other people;

- professional competences - competences necessary for a successful professional activity on the chosen specialty. It corresponds to a role "expert" - a person (worker) who is carrying out his functions on the level not below professional standards;

- $\quad$ practice in the sphere of activity forms understanding of competences use in a real context, including a branch, a region, interaction inside a company. It corresponds to a role "professional" - an expert, capable of mastering adjacent spheres of activity, understanding an interrelation of business processes and his role in them;
- creation of a new workplace for yourself (in the form of self-employment or in a company) and others (startups, business projects, cooperatives), implementation of a scientific or public project (creation of activity sphere for yourself). They correspond to roles "cooperator", "businessman", "researcher" - creators of new activity spheres.

Special concrete requirements (characteristics) of graduate products are defined for each education level.

Realization of such an approach is promoted in particular by holding a national championship "Career in Russia". The national championship of professions and enterprise ideas "Career in Russia" represents a duplicated educational technology 2.0. for the productive enterprise and design development of youth in Russian regions. It is carried out in a format of an annual cycle spectacular qualification "competitions and effectiveness trainings" on real working platforms of small and medium business enterprises, consumer cooperation, average professional educational institutions and higher education institutions.

Within such an approach to educational activity modernization in the departmental higher education institution and its branches Central union of Russian Federation consumer societies held a large-scale federal event devoted to cooperation development and its future on February 8, 2018 in Ulyanovsk - an all-Russian forum "New Cooperation".

In the run-up to the forum, from February 5 to February 7, the educational organizations leaders of consumer cooperation met for studying of the most topical issues of enterprise and career development of cooperative youth potential. Applications of 200 leaders were supported by microgrants in the form of food and accommodation payment, logistics on the platform and an organizational contribution.

In our opinion the development of such a powerful educational complex has become a natural policy continuation of Central union of Russian Federation consumer societies in respect to the system modernization of cooperative education in the recent years. At the same time the purpose of a continuing reforming consists first of all in providing requirements of reviving cooperative organizations for highly qualified personnel and also in carrying out indissoluble connection of theoretical knowledge with production and with social activity of cooperative structures.

However, it should be noted that today in agro-industrial complex of the Volgograd region as well as in the country in general the question of a new agrarian educational strategy formation is particularly acute. In our opinion in this strategy it is necessary to solve two main targets. Firstly, to support the current situation concerning personnel security of branches of agrarian and industrial complex on the level of the region and its social and economic orientation and, secondly, to create strategic directions for further improvement of agrarian business in it.

Besides now current agrarian education, where a cooperative educational system is its component, has to consider the fact that about $35 \%$ of all working are still engaged in an agro-industrial sector of our country economy 
and taking into account the realization of a course towards import substitution their quantity will only increase.

Considering the above we think that the development of cooperative and agrarian sectors is in many respects connected with modernization of educational system and expansion of actions for personnel training. In an educational process it is necessary to use actively new information and communication technologies, including remote technologies. It will allow to resolve an issue not only on personnel training without its separation from rural lifestyle, but also to improve additional education and skills of already working experts.

\section{CONCLUSION}

A. Personnel training is a difficult but at the same time a system and complex process in an administrative activity of any enterprise. New educational technologies emergence along with proved traditional personnel training methods is directed to timely mastering knowledge by workers and skills for their professional activity. Personnel training system has to be aimed at targets and strategy achievement of a company. Therefore, training problems are always directly connected with strategic and tactical plans of a company. The main thing is to provide training adequacy in enterprise requirements in the conditions of turbulent economy.

For Russian economy the problem of experts training has always played a key role both for the development of civil society and for the improvement of economic relations. International practice also shows that investments into personnel training provide a maximum return as the competence of workers is the base of sustainable development of any organization in the conditions of so-called "knowledge economy".

B. Cooperation is now a historically developed and demanded, economic structure and organizational form of interaction for agro-industrial complex of our country.

Consumer cooperation is a structural element of the Russian civil society, whose development is obviously an important aspect for modernization of a current agrarian sector of our country. Now the development of managing cooperative forms becomes one of the priority directions of the state agrarian policy. However, it is obvious that the revival of consumer cooperatives and other small forms of farming in many respects is defined by professionalism and skill level of its workers. Therefore, training, employment of competent experts and fixing them in a workplace continue to remain one of the main and strategic objectives in the modern Russian system of agrarian and cooperative education.

\section{References}

[1] Popova V. Production and operations management: manual. St. Petersburg: Peter, 2014. 336 pp. [Popova V. Upravlenie proizvodstvom i operatsiyami: Uchebnoe posobie. SPb.: Piter, 2014. 336 s.]

[2] Beshkinskaya E. Transition to the innovative type of economy development and continuous professional education // Person and work [Perekhod $\mathrm{k}$ innovatsionnomu tipu razvitiya ekonomiki i nepreryvnoe professional'noe obrazovanie // Chelovek i trud] 2009. Vol. 6. - P. 42-45. [Beshkinskaya E. Perekhod k innovatsionnomu tipu razvitiya ekonomiki i nepreryvnoe professional'noe obrazovanie // Chelovek i trud. 2009. № 6. - S. 42-45.]

[3] Philosophy Dialectic laws and the principles as the bases of scientific knowledge. [Filosofiya Dialekticheskie zakony i printsipy kak osnovaniya nauchnogo poznaniya] Available at (access mode): http://yhdgbfhjng.ru/filosofiya/filosofiya45.html [Filosofiya Dialekticheskie zakony i printsipy kak osnovaniya nauchnogo poznaniya - Rezhim dostupa: http://yhdgbfhjng.ru/filosofiya/filosofiya45.html]

[4] Системный подход в педагогике - Режим доступа: http://fb.ru/article/283334/sistemnyiy-podhod-v-pedagogike-primer

System approach in pedagogy [Sistemnyi podkhod $\mathrm{v}$ pedagogike] Available at (access mode): http://fb.ru/article/283334/sistemnyiypodhod-v-pedagogike-primer

[5] Official Internet portal of Federal State Statistics Service. - electronic text data. [Ofitsial'nyi internet-portal federal'noi sluzhby gosudarstvennoi statistiki. - Elektron. tekstovye dan.] Rezhim dostupa: http://www.gks.ru/ (data obrashcheniya: 23.10.2017).

[6] Final report on results of the analysis of the state and the prospects of development of a Volgograd region education system development for 2014. // Official portal of Committee on Education and science of the Volgograd region. - electronic text data [Itogovyi otchet o rezul'tatakh analiza sostoyaniya i perspektiv razvitiya sistemy obrazovaniya Volgogradskoi oblasti za 2014 god.// Ofitsial'nyi portal komiteta obrazovaniya i nauki Volgogradskoi oblasti] Available at (access mode): http://obraz.volganet.ru/current-activity/reports/ (data obrashcheniya: 01.03.2016).

[7] Volgograd region in figures. 2016: a brief collection. Territorial authority of Federal State Statistics Service in the Volgograd region. Volgograd: [Volgogradskaya oblast' v tsifrakh. 2016 : kratkii sb. Terr. organ Fed. sluzhby gos. statistiki po Volgograd. obl. - Volgograd : Volgogradstat] Volgogradstat, 2017. - 368 p.

[8] Inshakov O.V. Mechanism of social and market transformation and sustainable development of Russian agrarian and industrial complex. Volgograd $\therefore$ [Inshakov, O. V. Mekhanizm sotsial'no-rynochnoi transformatsii i ustoichivogo razvitiya APK Rossii. Volgograd.: Izd-vo VolGU, 450 s.] Publishing house of VolGU, $450 \mathrm{p}$.

[9] Vorotilova O.A., Obedkova L.V., Opeikina T.V. Modern Russian Practice of Investing in Human Capital Assets. Journal of Applied Economic Sciences.-. VolumeX, Issue 2 (32) Spring 2015. - P. 428-436.

[10] Official site of cooperation development institute [Ofitsial'nyi sait instituta razvitiya kooperatsii] Available at (access mode): https://ircoop.ru/11-rossijskie-organizatsii/45-minselkhoz-rossii

[11] Official site of the Russian Cooperation University [Ofitsial'nyi sait Rossiiskogo universiteta kooperatsii] Available at (access mode): http://www.ruc.su/ 